\title{
Occurrence of haemagglutinin mutation D222G in pandemic influenza $A(H 1 N 1)$ infected patients in the West of Scotland, United Kingdom, 2009-10
}

R S Miller ${ }^{1}$, A R MacLean (Alasdair.Maclean@ggc.scot.nhs.uk) ${ }^{1}$, R N Gunson ${ }^{1}$, W F Carman ${ }^{1}$

1. West of Scotland Specialist Virology Centre, Glasgow, United Kingdom

Citation style for this article:

Citation style for this article: Miller RS, MacLean AR, Gunson RN, Carman WF. Occurrence of haemagglutinin mutation D222G in pandemic influenza A(H1N1) infected patients in the West of Scotland, United Kingdom, 2009-10. Euro Surveill. 2010;15(16):pii=19546. Available online: http://www.eurosurveillance.org/ViewArticle. aspx?Articleld $=19546$

This article has been published on 22 April 2010

To the editor: Kilander et al. (2010) [1] have previously reported that in some cases of patients with severe or fatal pandemic influenza $A\left(\mathrm{H}_{1} \mathrm{~N}_{1}\right)$, an amino acid substitution from aspartic acid to glycine occurs at position $222\left(D_{222}\right.$ ) of the HA1 subunit of haemagglutinin (HA). In their study 11 (18\%) of 61 patients with severe disease had the mutation, in contrast to o of 205 patients with mild disease.

Since the original report [1] several countries have detected this mutation [2]. This data has been summarised in a recent World Health Organization (WHO) review, which reported that the overall prevalence of D222G was $<1.8 \%$ in contrast to a rate of $7.1 \%$ in fatal cases [2]. The WHO paper also reports on the occurrence of other mutations at this amino acid, D222E and $\mathrm{D} 222 \mathrm{~N}$, although their significance is unclear. A group in Hong Kong have also analysed this amino acid in severe and non-severe cases of pandemic influenza $\mathrm{A}\left(\mathrm{H}_{1} \mathrm{~N}_{1}\right)$ [3]. In this study nine $(4.1 \%)$ of 219 severe or fatal cases of pandemic influenza $A\left(\mathrm{H}_{1} \mathrm{~N}_{1}\right)$ had the D222G mutation, in contrast to o of 239 non-severe cases.

We sequenced the HA1 subunit of the HA gene from a number of West of Scotland cases, both community cases and severely ill. Furthermore we subdivided the severely ill into those who had died and those who recovered after hospitalisation. We found an increased incidence of $\mathrm{D} 222 \mathrm{G}$ in those patients who died (2/23

\section{TABLE}

Prevalence of mutations at amino acid D222 of

haemagglutinin of influenza A(H1N1), Scotland, United Kingdom, 2009-2010

\begin{tabular}{|l|c|c|c|c|}
\hline & $\begin{array}{c}\text { Number of } \\
\text { patients }\end{array}$ & D222G & D222N & D222E \\
\hline All cases & 58 & $2(3.4 \%)$ & $2(3.4 \%)$ & $4(6.9 \%)$ \\
\hline Patients who died & 23 & $2(8.7 \%)$ & 0 & $1(4.3 \%)$ \\
\hline Seriously ill patients & 9 & 0 & $2(22 \%)$ & $1(11 \%)$ \\
\hline Community patients & 26 & 0 & 0 & $3(11 \%)$ \\
\hline
\end{tabular}

- 8.7\%) compared to both community and hospitalised patients (0/35 - 0\%). We also detected an increased incidence (2/32 - 6.2\% cf o/26 - o\%) of D222N (aspartic acid to asparigine) in severely ill patients and those who had died. The significance of this mutation is unclear. There was a low level of D222E (aspartic acid to glutamic acid) present in both severely ill and community cases with no significant difference between the two. The results are summarised in the Table.

Interestingly, in one of the patients who died and had the $\mathrm{D} 222 \mathrm{G}$ mutation, the original sequence had a mixed base in the $\mathrm{D} 222$ codon giving D222D/G. On resequencing two more samples from this patient, we obtained a pure $\mathrm{D} 222 \mathrm{G}$ on one occasion and a pure wildtype D222 on the other, showing that this patient had a mixed population of virus. This confirms the finding in Kilander's paper [1] of the co-existence of mutant and wildtype virus.

\section{References}

1. Kilander A, Rykkvin R, Dudman S, Hungnes O. Observed association between the HA1 mutation D222G in the 2009 pandemic influenza $A\left(\mathrm{H}_{1} \mathrm{~N}_{1}\right)$ virus and severe clinical outcome, Norway 2009-2010. Euro Surveill. 2010;15(9) pii=19498. Available from: http://www.eurosurveillance.org/ViewArticle. aspx?Articleld $=19498$

2. World Health Organization. Preliminary review of D222G amino acid substitution in the haemagglutinin of pandemic influenza $A\left(H_{1} N_{1}\right) 2009$ viruses. Wkly Epidemiol Rec. 2010;85(4):21-2.

3. Mak GC, Au KW, Tai LS, Chuang KC, Cheng KC, Shiu TC, Lim W. Association of D222G substitution in haemagglutinin of 2009 pandemic influenza $A\left(\mathrm{H}_{1} \mathrm{~N}_{1}\right)$ with severe disease. Euro Surveill. 2010;15(14). pii=19534. Available from: http://www. eurosurveillance.org/ViewArticle.aspx?Articleld=19534 